\title{
CORPORATE GOVERNANCE QUALITY ON SPECIFIC CASE OF ROMANIAN LISTED COMPANIES
}

\author{
Sorana Mihaela MANOIU \\ Babes-Bolyai University Cluj-Napoca \\ Maria Ionela DAMIAN \\ Babes-Bolyai University Cluj-Napoca \\ Jiři STROUHAL ${ }^{22}$ \\ University of Economics Prague
}

\begin{abstract}
The purpose of this paper is to analyse the compliance of Romanian listed companies with corporate governance codes. From 2010, the "Comply or Explain" Statement, which discloses if and how the corporate governance principles are applied, became mandatory for all companies listed on Bucharest Stock Exchange (BSE). The methodology employed is based on the analysis of the above mentioned Statements published for the period 2009-2013. Research aims to present through a longitudinal and qualitative study the evolution of the compliance with the BSE Corporate Governance Codes. Most of the observed companies made a step forward in what concerns corporate governance principles and over the study period they disclosed more information on their statements. On the other hand, we found cases where the statements made over the studied period contained inconsistencies for some principles. The implementation of corporate governance rules ensures transparent decision-making, based on clear rules and objectives, and increases shareholders' confidence in the company.
\end{abstract}

\section{KEY WORDS}

Corporate governance, comply or explain, listed companies, emerging economies, Romania.

\section{JEL CLASSIFICATION}

G39

\section{INTRODUCTION}

Corporate governance is a highly debated and interesting topic that represents a pylon in companies' life. We can say that good corporate governance is a bridge between management and

\footnotetext{
${ }^{22}$ Correspondence address: Jiří Strouhal, doc. Ing. Ph.D.; telephone: +420 224098 356; email address: jiri.strouhal@ vse.cz, University of Economics Prague, Department of Strategy, W. Churchill Square 4, 13067 Prague 3, Czech Republic
} 
shareholders/stakeholders that leads to transparency and the improvement of financial reporting process.

An outstanding issue of corporate governance, that needs to be debated, is the "comply or explain" principle. The concept of comply or explain has an important impact in Europe since 2006 when the European Commission (EC) introduced comply or explain for the first time in European law, issuing Directive 2006/46/EC of the European Parliament and of the Council that has been implemented by the vast majority of Member States (Keay, 2014, p. 282).

According to the European Corporate Governance Forum (ECGF) for the "comply or explain" principle to be applied, three elements must be present, namely: a real obligation to comply or explain; a high level of transparency, with coherent and focused disclosures; and a way for shareholders to hold company boards ultimately accountable for their decisions to comply or explain, and the quality of their disclosures (Statement of the European Corporate Governance Forum on the comply-or-explain principle, 2006, p. 1). A basic component of this principle is the public Statement concerning compliance or non-compliance of the companies with corporate governance codes.

The purpose of this paper is to analyze the compliance of Romanian listed companies with corporate governance codes. From 2010, the "Comply or Explain" Statement, which discloses if and how the corporate governance principles are applied, became mandatory for all companies listed on Bucharest Stock Exchange (BSE). Before this mandatory application, we can specify that, from our analysis of official document and websites, only a company from non-financial sector (C.N.T.E.E. Transelectrica) has voluntarily presented this statement.

\section{LITERATURE REVIEW}

In this segment of corporate governance that we analyze in our study, referring to "Comply or Explain" Statement/principle, we found different studies and opinions about the compliance with code provision. Some papers present the companies compliance with the recommendation of governance codes and, on the other hand, other articles present an analysis of the reasons for noncompliance and deviation from code provision, that in many cases are not sufficiently substantial or accurate. One of these studies is conducted by Campbell et.al. (2009) who analyzed the reasons for non-compliance of Polish listed companies based on 250 publicly available compliance statements filed in 2005 by the companies listed on Warsaw Stock Exchange.

In a more recent study, Keay (2014, p. 288) presented on his paper, at the section "statement associated with comply or explain", some diversity and significant opinions of others scholars about the percentage of companies' compliance with code provisions.

Luo and Salterio (2014, p. 460) construct in their paper named "Governance Quality in a "Comply or Explain" Governance Disclosure Regime" a board score measure based on the Canadian code's 47 "best practices", using the Canadian "comply or explain" corporate governance disclosure regime. This study represent an empirical analysis based on Tobin's Q proxy for one-year data from 2006. They found that this measure is strongly and positively associated with higher firm value and weakly and positively associated with better operational performance.

Salterio et. al. (2013) developed an analysis of best practices compliance by 742 Canadian public companies with the recommendations imposed by the Canadian Securities Administrators, that are voluntary adopted or explained. Authors compared this rate of compliance (39\% of companies completely compliant) with the one from 1334 Australian companies (74\% of companies 
completely compliant). They analysed sixteen corporate governance best practices that are common to the Canadian and Australian codes of governance. In conclusion they noticed that compliance by adoption of best practice is more common in Canada, whereas compliance by explanation is more common in Australia.

In their working paper No. 389 that was part of CBR Research Programme on Corporate Governance, Seidl et al. (2009) analyzed the compliance statements and reports of 257 largest listed companies in the UK (London Stock Exchange) and Germany (Frankfurt Stock Exchange). This empirical study is based on a derived taxonomy of forms of "explanation" presented in "Comply or Explain" statements that have been divided in two categories: one for full compliance and one for full non-compliance. The authors found these forms of "explanation" based in part on different logics of argumentation, and shows significant divergence in compliance patterns in the UK and Germany (about 60\% had at least one deviation from the code provision) which may be explained by differences in experience, culture and legal system (Seidl et.al., 2009).

Study on the mandatory disclosure of accounting information is extremely popular in theoretical studies (e.g. Lee and Tweedie, 1975; Arnold and Moizer, 1984; Abu-Nassar and Rutherford, 1996). These studies deal with specified regulations providing the format of provided information as well as the variety in data covered by the financial statements. According to Healy and Palepu (2001) these are the major factors affecting the managers' disclosure decisions: (1) capital market transactions, (2) corporate control contests, (3) stock compensation, (4) litigation, (5) proprietary costs, and (6) management talent signaling.

In December 2014 came in force an update of accounting Directive 2013/34/EU on Disclosure of Non-Financial and Diversity Information by Certain Large Companies. Based on the Brussels view, first company reports including such information shall be published in 2018 covering financial year 2017-2018 (Strouhal et al., 2015). According to this directive management report of large companies shall also cover corporate governance statement providing at least the following information:

(a) a reference to the following, where applicable:

(i) the corporate governance code to which the undertaking is subject,

(ii) the corporate governance code which the undertaking may have voluntarily decided to apply,

(iii) all relevant information about the corporate governance practices applied over and above the requirements of national law,

(b) where an undertaking departs from a corporate governance code, an explanation by the undertaking as to which parts of the corporate governance code it departs from and the reasons for doing so; where the undertaking has decided not to refer to any provisions of a corporate governance code, it shall explain its reasons for not doing so;

(c) a description of the main features of the undertaking's internal control and risk management systems in relation to the financial reporting process;

(d) the information required by Directive 2004/25/EC on takeover bids;

(e) unless the information is already fully provided for in national law, a description of the operation of the shareholder meeting and its key powers and a description of shareholders' rights and how they can be exercised;

(f) the composition and operation of the administrative, management and supervisory bodies and their committees; and

(g) a description of the diversity policy applied in relation to the undertaking's administrative, management and supervisory bodies with regard to aspects such as, for instance, age, gender, or educational and professional backgrounds, the objectives of that diversity policy, how it has been implemented and the results in the reporting period. If no such policy is applied, the statement shall contain an explanation as to why this is the case. 


\section{RESEARCH DESIGN AND METHODOLOGY}

The methodology employed is based on the analysis of the "Explain or Complain" Statements published for the period 2009-2013. This research aims to present through a longitudinal and qualitative study the evolution of the compliance with the Bucharest Stock Exchange (BSE) Corporate Governance Codes.

In order to achieve our goal, we select only the companies listed at premium (first tier) category at Bucharest Stock Exchange (BSE) in order to have a homogeneous sample and because the probability to have the "Explain or Complain" Statements and all the information that we need in this analysis on the companies websites is higher. Also we consider that these companies have been adopted in a voluntary way and complied with the BSE Corporate Governance Code. Therefore, the selected sample is formed from 22 companies (10 belonging to the financial sector and 12 nonfinancial sector companies). According to the BSE Press Release from December 2014, since 15 January 2015 BSE has a new market segmentation, the first category was replaced with the premium one and the second and third categories were replaced with the standard ones (www.bvb.ro).

Sources where we found the "Comply or Explain" Statement for the analysis period from 2009 and at the most recent version (2013), are the official data published by listed companies on their websites (see Appendix 2), such as the Annual Report, the Supervisory Board's Report, Corporate Governance Code and Bucharest Stock Exchange (BSE) website.

We further developed a disclosure scoring criteria awarding scores of 1-3 based on a Likert scale for items disclosed and ' 0 ' otherwise. Therefore, codifing the responses presented in "Comply or Explain" Statement we have the following possibilities:

0 - full non-compliance or not applicable. Some companies specify that for them some principle/recommendation from Corporate Governance Code is not applicable (N/A) or they responded with "No" or "No, not in scope" without giving an explanation for noncompliance.

1 - non-compliance, but explained. In this category we inserted the negative responses with meaningful and plausible explanation.

2 - partial compliance. We codified with 2 the affirmative but not complete responses, for example "Yes, work in progress" or those cases where only a part of recommendation is applied.

3 - full compliance.

We assume the fact that these statements were made correctly, according to the Corporate Governance Code, Constitutive Act and other important statements of companies.

Then, we calculated the percentage score for each company per years based on the above codification and by using the following formula:

Company's score per year $=\frac{0 * A+1 * B+2 * C+3 * D}{\mathbf{S 1} * 3} * 100$

where:

A - the number of full non-compliance or not applicable responses

$\mathrm{B}$ - the number of non-compliance, but explained responses

$\mathrm{C}$ - the number of partial compliance responses

$\mathrm{D}$ - the number of full compliance responses

51 - the total number of questions/recommendations 


\section{DEVELOPING THE ANALYSIS AND COMMENTING THE OBTAINED RESULTS}

The Bucharest Stock Exchange, through the Corporate Governance Code which is applied since 2008, lays down principles and/or recommendations which are not mandatory, but listed companies must comply with them or explain why they are not complying with some of their provisions. For this reason, from 2010, listed companies must to prepare the "Comply or Explain" Statement that has a mandatory and public application, which explains the areas of compliance as well as the reasons for non-compliance. 
Table 1 Financial companies score

\begin{tabular}{|c|c|c|c|c|c|c|c|c|c|c|c|c|c|c|c|c|c|c|c|c|c|c|}
\hline \multirow[b]{2}{*}{ Symb. } & \multirow[b]{2}{*}{ Companies } & \multirow[t]{2}{*}{2009} & \multicolumn{4}{|c|}{2010} & \multirow{2}{*}{$\begin{array}{l}\text { Total } \\
2010 \\
\% \\
\end{array}$} & \multicolumn{4}{|c|}{2011} & $\begin{array}{l}\text { Total } \\
2011 \\
\end{array}$ & \multicolumn{4}{|c|}{2012} & $\begin{array}{l}\text { Total } \\
2012 \\
\end{array}$ & \multicolumn{4}{|c|}{2013} & \multirow{2}{*}{$\begin{array}{c}\text { Total } \\
2013 \\
\% \\
\end{array}$} \\
\hline & & & $\mathbf{0}$ & 1 & 2 & 3 & & $\mathbf{0}$ & 1 & 2 & 3 & $\%$ & $\mathbf{0}$ & 1 & 2 & 3 & $\%$ & $\mathbf{0}$ & 1 & 2 & 3 & \\
\hline $\mathrm{BCC}$ & $\begin{array}{l}\text { BANCA } \\
\text { COMERCIA } \\
\text { LA } \\
\text { CARPATIC } \\
\text { A S.A }\end{array}$ & N/A & - & 1 & 1 & 49 & $98.04 \%$ & - & 1 & - & 50 & $98.69 \%$ & - & 1 & - & 50 & $98.69 \%$ & - & - & - & 51 & $100.00 \%$ \\
\hline TLV & $\begin{array}{l}\text { BANCA } \\
\text { TRANSILV } \\
\text { ANIA S.A } \\
\end{array}$ & N/A & \multicolumn{5}{|c|}{$\begin{array}{l}\text { the information cannot be } \\
\text { found on the website }\end{array}$} & 10 & 3 & - & 38 & $76.47 \%$ & 10 & 3 & - & 38 & $76.47 \%$ & 6 & 3 & - & 42 & $84.31 \%$ \\
\hline BRD & $\begin{array}{l}\text { BRD } \\
\text { GROUPE } \\
\text { SOCIETE } \\
\text { GENERALE } \\
\text { S.A. }\end{array}$ & N/A & - & 9 & - & 42 & $88.24 \%$ & - & 5 & - & 46 & $93.46 \%$ & - & 5 & - & 46 & $93.46 \%$ & - & 5 & - & 46 & $93.46 \%$ \\
\hline FP & $\begin{array}{l}\text { FONDUL } \\
\text { PROPRIET } \\
\text { ATEA } \\
\end{array}$ & N/A & \multicolumn{5}{|c|}{$\begin{array}{l}\text { the information cannot be } \\
\text { found on the website }\end{array}$} & - & 1 & 1 & 49 & $98.04 \%$ & - & 1 & 1 & 49 & $98.04 \%$ & - & 1 & 1 & 49 & $98.04 \%$ \\
\hline BRK & $\begin{array}{l}\text { S.S.I.F. } \\
\text { BROKER } \\
\text { S.A. }\end{array}$ & N/A & \multicolumn{5}{|c|}{$\begin{array}{l}\text { the information cannot be } \\
\text { found on the website }\end{array}$} & 8 & 10 & - & 33 & $71.24 \%$ & 6 & 11 & - & 34 & $73.86 \%$ & 5 & 13 & - & 33 & $73.20 \%$ \\
\hline SIF1 & $\begin{array}{l}\text { SIF BANAT } \\
\text { CRISANA } \\
\text { S.A. }\end{array}$ & N/A & - & 3 & - & 48 & $96.08 \%$ & \multicolumn{5}{|c|}{$\begin{array}{l}\text { the information cannot be found } \\
\text { on the website }\end{array}$} & - & 3 & - & 48 & $96.08 \%$ & - & 3 & - & 48 & $96.08 \%$ \\
\hline SIF2 & SIF & N/A & - & 4 & - & 47 & $94.77 \%$ & - & 4 & - & 47 & $94.77 \%$ & - & 4 & - & 47 & $94.77 \%$ & - & 1 & - & 50 & $98.69 \%$ \\
\hline
\end{tabular}




\begin{tabular}{|c|c|c|c|c|c|c|c|c|c|c|c|c|c|c|c|c|c|c|c|c|c|c|}
\hline & $\begin{array}{l}\text { MOLDOVA } \\
\text { S.A. }\end{array}$ & & & & & & & & & & & & & & & & & & & & & \\
\hline SIF4 & $\begin{array}{l}\text { SIF } \\
\text { MUNTENI } \\
\text { A S.A. }\end{array}$ & N/A & - & 6 & 1 & 44 & $91.50 \%$ & - & 6 & 1 & 44 & $91.50 \%$ & - & 6 & 1 & 44 & $91.50 \%$ & - & 6 & - & 45 & $92.16 \%$ \\
\hline SIF5 & $\begin{array}{l}\text { SIF } \\
\text { OLTENIA } \\
\text { S.A. }\end{array}$ & N/A & - & 12 & - & 39 & $84.31 \%$ & - & 6 & - & 45 & $92.16 \%$ & - & 6 & - & 45 & $92.16 \%$ & - & 9 & - & 42 & $88.24 \%$ \\
\hline SIF3 & $\begin{array}{l}\text { SIF } \\
\text { TRANSILV } \\
\text { ANIA S.A. }\end{array}$ & N/A & - & 6 & - & 45 & $92.16 \%$ & - & 6 & - & 45 & $92.16 \%$ & - & 5 & - & 46 & $93.46 \%$ & - & 4 & - & 47 & $94.77 \%$ \\
\hline
\end{tabular}

(Source: authors' computation) 
Within Table 1 we presented the codifications for the financial companies listed in the premium (first tier) category at Bucharest Stock Exchange. The analysis was made for the period 2009-2013, in order to see the evolution of disclosure on corporate governance principles of these entities before and after the mandatory application of "Comply and Explain" Statement for the listed entities (2010). We can observe that in 2009 no entity presented in a voluntary way the statement. From 2010, after the mandatory application, we found official information (on the Bucharest Stock Exchange or entities 'websites) only for 7 out of 10 Romanian financial listed entities.

In 2014, the only financial entity that is fully compliant with all 19 principles/recommendations from BSE Corporate Governance Code is Banca Comerciala Carpatica S.A. The only noncompliance explained for this company, in the first 3 years from mandatory adoption, was the nondisclosure of information in English. Since 2013 this company discloses periodical and permanently information in this international language. The lowest compliance with the principles we can observe at the company S.S.I.F. Broker S.A. which has obtained only $73.20 \%$ for 2013's declaration based on the presented codification. The above mentioned company and Banca Transilvania S.A. are the only two financial companies that gave negative answers on "Comply or Explain" Statements that were not explained, as this declaration require. This type of answers has a zero scoring in our analysis.

We can see that the evolution of most companies contained in Table 1 is going in a good direction, that is to present and take care of the recommendations made by BSE. For example, SIF Muntenia S.A. has improved the remuneration policy (P10-R21-please see the Appendix 1), BRD - Groupe Societe Generale S.A has drawn up from 2011 a Corporate Governance Regulation which describes the main aspects of the corporate governance principles (corporate governance structures, positions, competences and responsibilities of the Supervisory Board and of the Executive Board) and posted it on the company's website (P1-R1, R2), and from 2013 established a Nomination Committee (P10).

SIF Oltenia S.A. presented a full compliance on its "Comply or Explain" Statements from years 2010, 2011 and 2012 in what concerns the question "Does the Supervisory Board or the Audit committee, as the case may be, assess on a regular basis the efficiency of financial reporting, internal control and the risk management system implemented by the Issuer?" (P12, P13-R28, www.sifolt.ro) and then in 2013 specify that Audit committee did not prepared and did not submitted analysis documents to Supervisory Board. Based on 19 principles that the issuer is managed in a two-tier system, only two companies (Banca Comerciala Carpatica S.A, SIF Transilvania S.A.) complied this recommendation. Two-tier system (German or Austrian Model) is implemented to improve corporate governance and is based on two different management structures: Supervisory Board (non-executive members) and Executive Board, compared to one tier board (UK or USA Model) where we have only a Board containing executive and non-executive members.

In order to show the evolution of compliance with BSE Corporate Governance Code we present the following Figure 1: 


\section{Figure 1 Evolution of compliance score for listed companies}

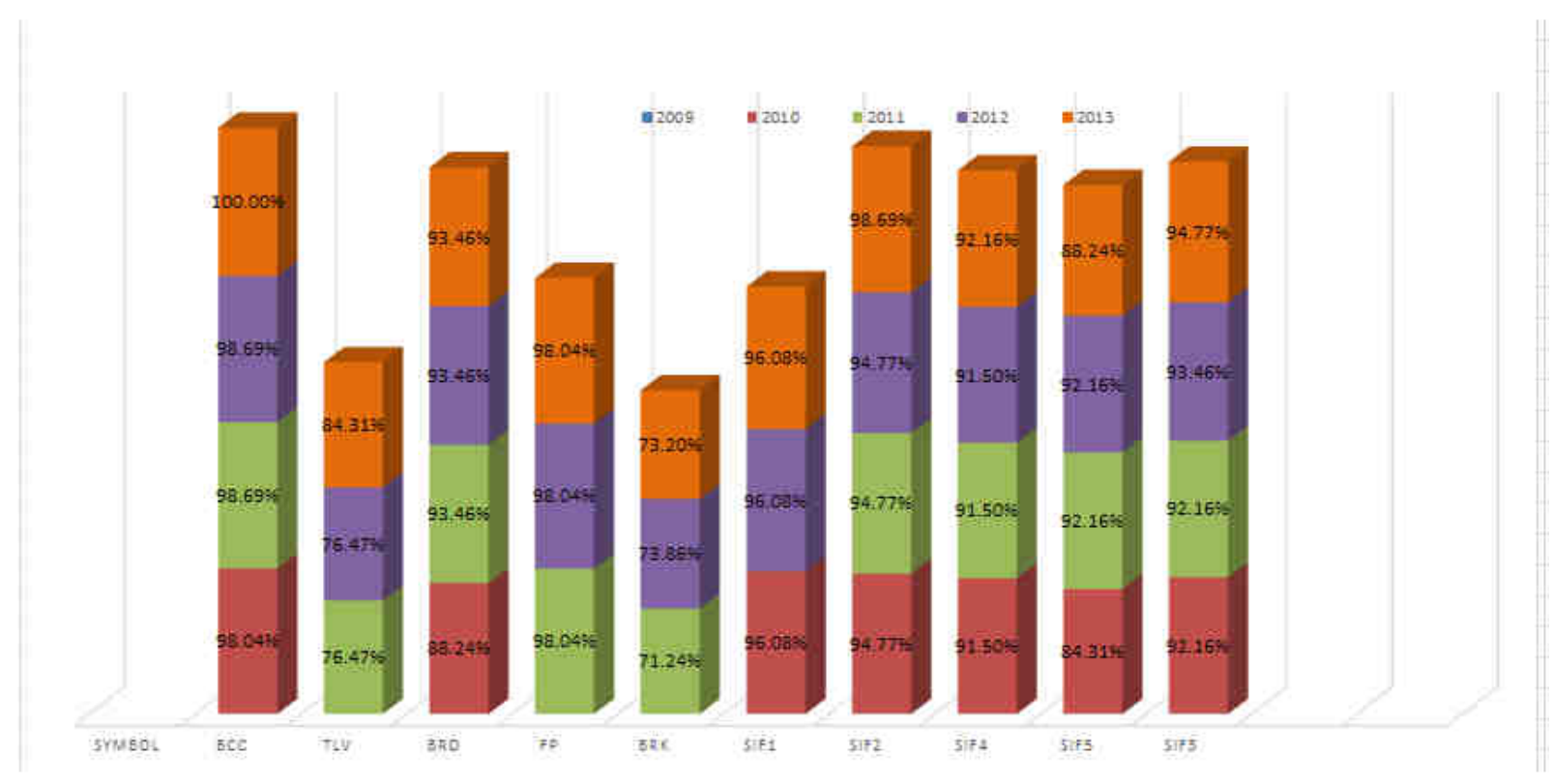

(Source: authors' computation)

For three companies (BCC, FP, BRK) we could not find the "Comply or Explain" Statement for years 2010, and for the company SIF Banat Crisana S.A. (SIF1) the Statement from 2011 was not found.

Observing this figure we can notice that there are three types of company evolution based on compliance with corporate governance code: (i) the increasing score meaning that the compliance with principles increased yearly; (ii) the stagnation score meaning that company presented the same compliance within analysed period; (iii) the decreasing score meaning the company changed the application of corporate governance principles and presented a lower compliance.

In the first category we can include the majority of the companies: Banca Comerciala Carpatica S.A.; Banca Transilvania S.A.; BRD-Groupe Societe General S.A. that have an increasing score in year 2011, then it remains at the same level; SIF Moldova S.A.; SIF Muntenia S.A.; SIF Transilvania S.A.

We can observe a stagnation score that was obtained based on our calculation, in the cases of Fondul Proprietatea (98.04\%) and SIF Banat Crisana S.A. companies (96, 08\%). These two companies were managed in a first tier board and have obtained a good score along the analysis period. These companies conduct their corporate governance based on BSE Corporate Governance Code, or have a plausible explanation for non-compliance.

In the third category we have the following companies: SIF Oltenia S.A. and SSIF Broker S.A. In case of the first company, after presenting in 2011 and 2012 a positive answer (score-3) at the question "In the course of its activity, is the Supervisory Board supported by any consultative commissions/committees nominated by the Supervisory Board, which deal with the analysis of some specific subjects in order to counsel the Supervisory Board on such topics? " (P8-R15, please see Appendix 1, www.sifolt.ro) in 2013, the answer provided was "No", with explanation (score-1) that until now certain topics have not been selected for analyse. Also the answer to the principle P11R21 has been changed from "Yes" in 2010 to "No" with the explanation that the remuneration 
policy was established in General Meetings of Shareholders ("GMS") and the number of independent Supervisory Board members is insufficient. 


\section{Table 2 Non-financial companies score}

\begin{tabular}{|c|c|c|c|c|c|c|c|c|c|c|c|c|c|c|c|c|c|c|c|c|c|c|c|c|c|c|}
\hline \multirow[b]{2}{*}{ Symb. } & \multirow[b]{2}{*}{ Companies } & \multicolumn{4}{|c|}{2009} & \multirow[t]{2}{*}{ Total 2009} & \multicolumn{3}{|c|}{2010} & \multicolumn{2}{|c|}{ Total 2010} & \multicolumn{4}{|c|}{2011} & \multirow[t]{2}{*}{$\begin{array}{l}\text { Total } \\
2011 \\
\end{array}$} & \multicolumn{4}{|c|}{2012} & \multirow[t]{2}{*}{$\begin{array}{l}\text { Total } \\
2012 \\
\end{array}$} & \multicolumn{4}{|c|}{2013} & \multirow[t]{2}{*}{ Total 2013} \\
\hline & & $\mathbf{0}$ & 1 & 2 & 3 & & $\mathbf{0}$ & 1 & 2 & 3 & & $\mathbf{0}$ & 1 & 2 & 3 & & $\mathbf{0}$ & 1 & 2 & 3 & & $\mathbf{0}$ & 1 & 2 & 3 & \\
\hline ATB & ANTIBIOTICE S.A. & \multicolumn{5}{|c|}{ N/A } & 6 & 2 & 2 & 41 & $84.31 \%$ & \multicolumn{5}{|c|}{$\begin{array}{l}\text { the information cannot be found on } \\
\text { the website }\end{array}$} & 1 & - & - & 50 & $98.04 \%$ & 1 & - & - & 50 & $98.04 \%$ \\
\hline $\mathrm{BIO}$ & BIOFARM S.A. & \multicolumn{5}{|c|}{ N/A } & 11 & 3 & - & 37 & $74.51 \%$ & 4 & 2 & - & 45 & $89.54 \%$ & 2 & 9 & - & 40 & $84.31 \%$ & 2 & 9 & - & 40 & $84.31 \%$ \\
\hline BVB & $\begin{array}{l}\text { BURSA DE VALORI } \\
\text { BUCURESTI SA }\end{array}$ & \multicolumn{5}{|c|}{ N/A } & \multicolumn{5}{|c|}{$\begin{array}{l}\text { the information cannot be found on } \\
\text { the website }\end{array}$} & \multicolumn{5}{|c|}{$\begin{array}{l}\text { the information cannot be found on } \\
\text { the website }\end{array}$} & 1 & 16 & - & 34 & $77.12 \%$ & 1 & 11 & - & 39 & $83.66 \%$ \\
\hline TEL & $\begin{array}{c}\text { C.N.T.E.E. } \\
\text { TRANSELECTRICA } \\
\end{array}$ & & 9 & & $\begin{array}{l}4 \\
2 \\
\end{array}$ & $88.24 \%$ & - & 9 & - & 42 & $88.24 \%$ & - & 9 & - & 42 & $88.24 \%$ & 1 & 5 & - & 45 & $91.50 \%$ & 1 & 6 & - & 44 & $90.20 \%$ \\
\hline COTE & CONPET SA Ploiesti & \multicolumn{5}{|c|}{ N/A } & \multicolumn{5}{|c|}{$\begin{array}{l}\text { the information cannot be found on } \\
\text { the website }\end{array}$} & \multicolumn{5}{|c|}{$\begin{array}{l}\text { the information cannot be found on } \\
\text { the website }\end{array}$} & \multicolumn{5}{|c|}{$\begin{array}{l}\text { the information cannot be found on } \\
\text { the website }\end{array}$} & 4 & 2 & - & 45 & $89.54 \%$ \\
\hline EL & ELECTRICA SA & \multicolumn{5}{|c|}{ N/A } & \multicolumn{5}{|c|}{$\begin{array}{l}\text { the information cannot be found on } \\
\text { the website }\end{array}$} & \multicolumn{5}{|c|}{$\begin{array}{l}\text { the information cannot be found on } \\
\text { the website }\end{array}$} & \multicolumn{5}{|c|}{$\begin{array}{l}\text { the information cannot be found on } \\
\text { the website }\end{array}$} & \multicolumn{5}{|c|}{$\begin{array}{l}\text { the information cannot be found on the } \\
\text { website }\end{array}$} \\
\hline ELMA & $\begin{array}{l}\text { ELECTROMAGNETIC } \\
\text { A SA BUCURESTI }\end{array}$ & \multicolumn{5}{|c|}{ N/A } & \multicolumn{5}{|c|}{$\begin{array}{l}\text { the information cannot be found on } \\
\text { the website }\end{array}$} & 2 & 25 & - & 24 & $63.40 \%$ & 6 & 20 & 1 & 24 & $61.44 \%$ & 4 & 17 & 1 & 29 & $69.28 \%$ \\
\hline IMP & $\begin{array}{c}\text { IMPACT } \\
\text { DEVELOPER \& } \\
\text { CONTRACTOR S.A } \\
\end{array}$ & & & & N/A & & the & nforn & $\begin{aligned} \text { ation } \\
\text { the }\end{aligned}$ & $\begin{array}{l}\text { cann } \\
\text { websi }\end{array}$ & be found on & & ormat & $\begin{array}{l}\text { on ca } \\
\text { he we }\end{array}$ & $\begin{array}{ll}\text { anot } \\
\text { bsite }\end{array}$ & found on & 2 & 6 & - & 43 & $88.24 \%$ & 2 & 6 & - & 43 & $88.24 \%$ \\
\hline SNP & OMV PETROM S.A. & & & & N/A & & - & 6 & - & 45 & $92.16 \%$ & - & 6 & - & 45 & $92.16 \%$ & - & 5 & - & 46 & $93.46 \%$ & - & 5 & - & 46 & $93.46 \%$ \\
\hline SNN & $\begin{array}{c}\text { S.N. } \\
\text { NUCLEARELECTRIC } \\
\text { A S.A. } \\
\end{array}$ & & & & N/A & & the & nforn & $\begin{aligned} \text { ation } \\
\text { the }\end{aligned}$ & $\begin{array}{l}\text { cann } \\
\text { websi }\end{array}$ & be found on & & ormat & $\begin{array}{l}\text { on ca } \\
\text { he we }\end{array}$ & $\begin{array}{ll}\text { anot } \\
\text { bsite }\end{array}$ & found on & & $n$ for & & nsot & found on & - & 3 & - & 48 & $96.08 \%$ \\
\hline SNG & $\begin{array}{l}\text { S.N.G.N. ROMGAZ } \\
\text { S.A. }\end{array}$ & & & & N/A & & the & nforn & $\begin{aligned} \text { ation } \\
\text { the }\end{aligned}$ & $\begin{array}{l}\text { cann } \\
\text { websi }\end{array}$ & be found on & & ormat & $\begin{array}{l}\text { on ca } \\
\text { ne we }\end{array}$ & $\begin{array}{l}\text { anot } \\
\text { bsite }\end{array}$ & found on & & nforr & & $\begin{array}{l}\text { annot } \\
\text { ebsite }\end{array}$ & found on & - & 11 & - & 40 & $85.62 \%$ \\
\hline TGN & $\begin{array}{c}\text { S.N.T.G.N. } \\
\text { TRANSGAZ S.A. } \\
\end{array}$ & & & & N/A & & - & 5 & - & 46 & $93.46 \%$ & - & 4 & - & 47 & $94.77 \%$ & - & 4 & - & 47 & $94.77 \%$ & - & 4 & - & 47 & $94.77 \%$ \\
\hline
\end{tabular}

(Source: authors' computation) 
Taking a "snapshot" of Table 2 we can see the codifications for the non-financial companies listed in the premium (first tier) category at Bucharest Stock Exchange. We made this separation between the financial and non-financial companies because the first ones need to apply different regulations and laws, so this aspect may cause differences, if we are referring to the compliance with BSE Corporate Governance Code and the filling of "Comply or Explain" Statement.

We can observe that there is only one company (C.N.T.E.E. Transelectrica) presented this statement before the mandatory request across all the listed ones in the premium category of BSE.

The scores obtained by each company are based on the presented codification and we can notice that many of these companies have in their composition the scoring zero based on our codification. This means that on the "Comply or Explain" Statements are negative answers without explanation, as the Statement required.

For the company Electrica S.A. we cannot find the information ("Comply or Explain" Statements) on the company or Bucharest Stock Exchange websites, therefore this company was excluded from our analysis.

In 2013 Antibiotice S.A. is first in the top of complied listed company with BSE Corporate Governance Code, from the non-financial sector. This company has obtained a score of $98.04 \%$ based on the presented codification, even if we do not found the Statement for the financial year 2011. Antibiotice S.A. has develop along studied period some aspects related to corporate governance, such as posted on the issuer website the Statute/Corporate Governance Regulation (mentioning the date of its last update), disclose on its website the information related to the corporate governance policy (P1-R3), ensure a balance between the executive and non-executive members (P6), provide a sufficient number of independent members (P7). On the other hand, at the bottom of the ranking companies we have the company Electromagnetica S.A. Bucuresti with an obtained score of $69.28 \%$.

In some cases, the Statements made over the studied period contained inconsistencies for some principles. For example, presented a positive answer in 2010 and 2011 at the principle P11 -R22 "Is there a Biofarm S.A. Remuneration Committee made exclusively of nonexecutive members of the Supervisory Board?"(www.biofarm.ro) and in the next two years $(2012,2013)$ the response was "No, this Remuneration Committee will be set up on the next period". Another example for the same company, is on the principle P8 -R15 the answer for the year 2011 was "Yes" and then in the next two years was "No, is not the case".

Another company that presented inconsistency is Electromagnetica S.A. Bucuresti that in several years has a different answer with the same explanation in "Comply or Explain" Statement. In 2012 the answer at the principle P6 was "No" and in 2013 was "Yes", with the explanation "the Supervisory Board ensures a balance between executives and non-executives members (five from nine members are non-executives, but none of them matches the criteria to be an independent one)" (www.electromagnetica.ro).

In order to show the evolution of companies' compliance with BSE Corporate Governance Code we made the following Figure 2: 


\section{Figure 2 Evolution of compliance for non-financial companies}

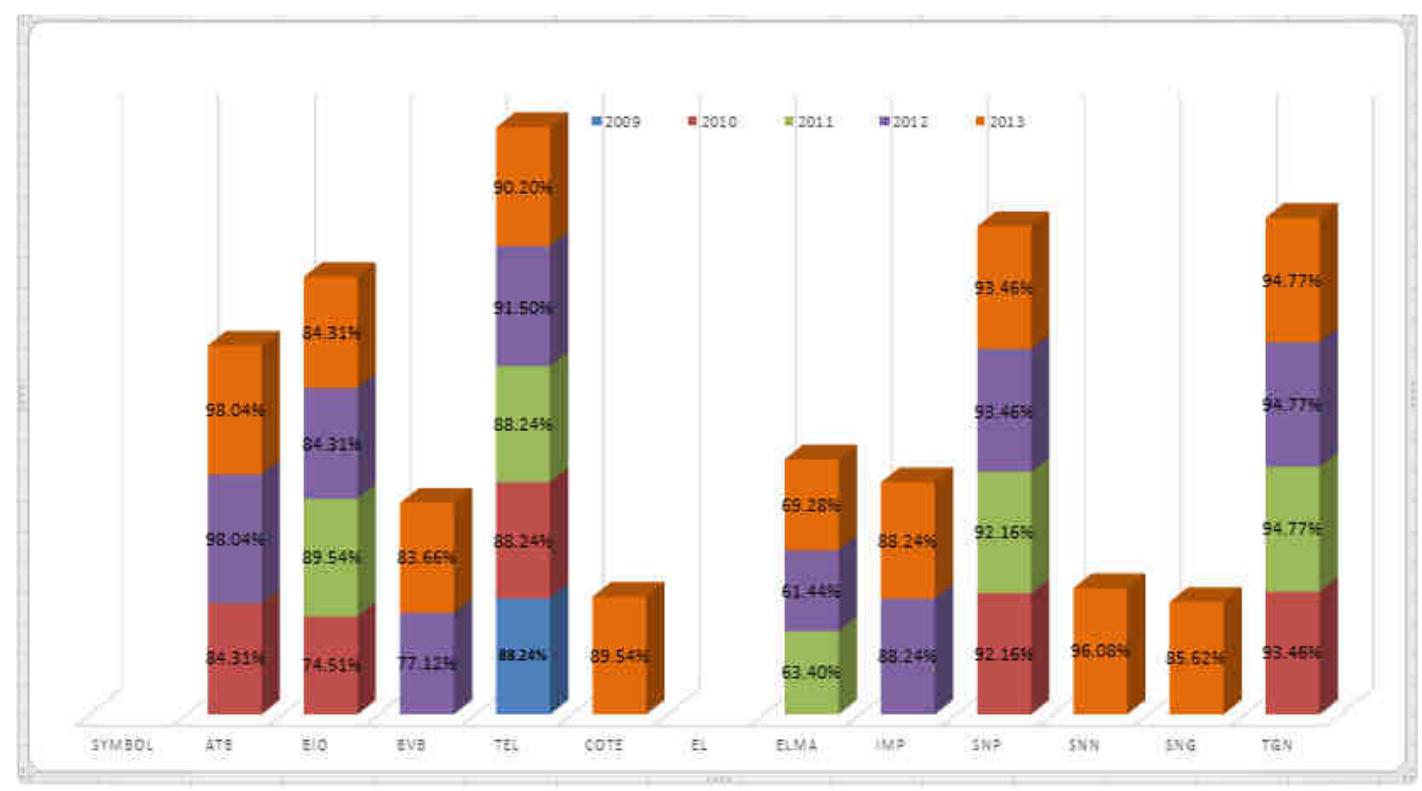

(Source: authors' computation)

For some companies we cannot make an evolution analysis of the compliance with BSE Corporate Governance Code because these companies did not post on their websites this declaration. Consequently, for companies Conpet S.A. Ploiesti, SN Nuclearelectrica S.A. and SNGN Romgaz S.A. we found only the data for year 2013.

Taking into account the three types of company evolution presented before, we can observed in the Figure no. 2 that only a company (Impact Developer \& Contractor S.A.) presented the stagnation score of $88.24 \%$ for two years. Also we introduced in this category the company SNTGN Transgaz S.A. that presenting a score of $94.77 \%$ for three years. The rest of the non-financial companies along studied period had a fluctuation in adopting and compliance with the governance code.

\section{CONCLUSIONS}

We assume in our study the fact that these statements are made correctly, according to the Corporate Governance Code, Constitutive Act and other important statements the companies. We conduct this analysis of "Comply or Explain" Statement based on the assumptions that "compliance by adoption" of BSE Corporate Governance codes principles/recommendation is superior to "noncompliance by explanation" or suggest that any action without adoption of principles/recommendation is "noncompliance."

From our analysis we excluded a non-financial company (Electrica S.A.) because we cannot found data ("Comply or Explain" Statement) in order to develop the analysis for the studied period of 2009-2013.

We made a distinction between financial and non-financial companies because the first ones have different regulations. Financial companies present a higher level of disclosure financial and nonfinancial information and are more compliant with the BSE Corporate Governance Code than nonfinancial companies. 
In order to better explain our analysis we presented three types of company evolution based on compliance with corporate governance code and place the analysis companies in the following evolution segments: the increasing score - means that the compliance with principles increased yearly; the stagnation score - this companies presented the same compliance on the analysis period; the decreasing score- means that companies changed their application of corporate governance principles and presented a lower compliance with principles/recommendations.

Concluding we have to point two remarks regarding this analysis: firstly, we found that only one company from the final sample (Banca Comerciala Carpatica S.A.) is fully compliant with all 19 principles/recommendations from BSE Corporate Governance Code and secondly, also only one company (C.N.T.E.E. Transelectrica) presented this statement before the mandatory request across all the listed ones in the premium category of BSE became effective.

Most of the observed companies made a step forward in what concerns corporate governance principles and over the study period they disclosed more information on their statements. On the other hand, we found cases where the statements made over the studied period contained inconsistencies (Biofarm S.A., Electromagnetica S.A. Bucuresti) for some principles and some companies had fluctuation along the analysed period in adopting and complied voluntary with BSC Corporate Governance Code.

The contemporary crisis reveals that the informative quality of explanations derived from the corporate governance code's recommendation and for many countries there is insufficient monitoring of the application of these codes (Nedelchev, 2013, p. 79).

The implementation of corporate governance rules ensures transparent decision-making, based on clear rules and objectives, and increases shareholders confidence in the company. Therefore, the degree of compliance with corporate governance principles has an important role in a company's life.

\section{Acknowledgement}

This paper was co-financed from the European Social Fund through Sectoral Operational Programme Human Resources Development 2007-2013, project number POSDRU/159/1.5/S/134197 „Performance and excellence in doctoral and postdoctoral research in Romanian economics science domain” and project IGA VŠE F3/2/2014 „Analysis of Reporting of Listed and Non-listed Companies in Selected EU Countries and China" financed by University of Economics Prague.

\section{REFERENCES}

Abu-Nassar, M. and Rutherford, B.A. (1996) External users of financial reports in less developed countries: the case of Jordan. British Accounting Review, No. 28, pp. 73-87.

Arnold, A. and Moizer, P. (1984) A survey of the methods used by UK investment analysts to appraise investments in ordinary shares. Accounting and Business Research, No. 14, pp. 195207.

Bucharest Stock Exchange (2014) Press Release from 23. 12. 2014, available at:

http://www.bvb.ro/AboutUs/MediaCenter/PressReleases

Campbell, K., Jerzemowska, M. \& Najman, K. (2009) Corporate Governance Challenges in Poland: Evidence from "Complain or Explain" Disclosures. Corporate Governance: The International Journal of Business in Society, Vol. 9, No. 5, pp. 623-634. 
European Corporate Governance Forum (2006) Statement of the ECGF on the Comply-or-Explain Principle, available at: http://ec.europa.eu/internal_market/company/docs/ecgforum/ecgfcomplyexplain_en.pdf

European Union (2013). Directive 2013/34/EU of the European Parliament and of the Council of 26 June 2013 on the annual financial statements, consolidated financial statements and related reports of certain types of undertakings, amending Directive 2006/43/EC of the European Parliament and of the Council and repealing Council Directives 78/660/EEC and 83/349/EEC. Retrieved from: http://eur-lex.europa.eu/legal-content/EN/TXT/?uri=celex:32013L0034.

Healy, P.M. and Palepu, K.G. (2001) Information asymmetry, corporate disclosure, and the capital markets: a review of the empirical disclosure literature. Journal of Accounting and Economics, Vol. 31, No. 1-3, pp. 405-440.

Keay, A. (2014) Comply or Explain in Corporate Governance Codes: In Need of Greater Regulatory Oversight? Legal Studies, Vol. 34, No. 2, pp. 279-304.

Lee, T.A. and Tweedie, D.P. (1975) Accounting Information: an investigation of private shareholder usage. Accounting Business Research, No. 6, pp. 280-291.

Luo, Y. \& Salterio, S. E. (2014) Governance Quality in a "Comply or Explain" Governance Disclosure Regime. Corporate Governance: An International Review, Vol. 22, No. 6, pp. 460481.

Nedelchev, M. (2013) Good Practices in Corporate Governance: One-Size-Fits-All vs. Comply-orExplain. International Journal of Business Administration, Vol. 4, No. 6, pp. 75-81.

Salterio, S. E., Conrod, J. E. D. \& Schmidt, R. N. (2013) Canadian Evidence of Adherence to "Comply or Explain" Corporate Governance Codes: An International Comparison. CAAA/ACPC, Vol. 12, No. 1, pp. 23-51.

Seidl, D., Sanderson, P. \& Roberts, J. (2009) Applying "Comply-or-Explain": Conformance with Codes of Corporate Governance in the UK and Germany. Centre for Business Research, University of Cambridge Working Paper No. 389.

Strouhal, J., Gurvitš, M., Nikitina-Kalamäe, M. \& Startseva, E. (2015) Finding the Link between CSR Reporting and Corporate Financial Performance: Evidence on Czech and Estonian Listed Companies. Central European Business Review, Vol. 4, No. 3, pp. 48-59. 
APPENDIX 1 - Model of "Comply or Explain" Statement

\begin{tabular}{|c|c|c|}
\hline \multicolumn{2}{|c|}{$\begin{array}{l}\text { Principle/ } \\
\text { Recommendation }\end{array}$} & Question \\
\hline \multicolumn{2}{|c|}{ P19 } & Is the issuer managed in a two tier system? \\
\hline \multirow{10}{*}{$\mathrm{P} 1$} & \multirow[t]{2}{*}{$\mathrm{R} 1$} & $\begin{array}{l}\text { Has the Issuer drawn up a Statute/Corporate Governance Regulation } \\
\text { which describes the main aspects of the corporate governance } \\
\text { principles? }\end{array}$ \\
\hline & & $\begin{array}{l}\text { Is the Statute/Corporate Governance Regulation (mentioning the } \\
\text { date of its last update) posted on the website of the Issuer? }\end{array}$ \\
\hline & $\mathrm{R} 2$ & $\begin{array}{l}\text { In the Statute/Corporate Governance Regulation, are there defined } \\
\text { corporate governance structures, positions, competences and } \\
\text { responsibilities of the Supervisory Board and of the Executive } \\
\text { Board? }\end{array}$ \\
\hline & \multirow{7}{*}{ R3 } & $\begin{array}{l}\text { Has the Annual Report of the Issuer a chapter referring to corporate } \\
\text { governance, which describes all the relevant events related to } \\
\text { corporate governance registered in the previous financial year? }\end{array}$ \\
\hline & & $\begin{array}{l}\text { Does the Issuer disclose on its website the information related to the } \\
\text { following aspects of its corporate governance: } \\
\text { a) a description of Issuer's corporate governance structures? }\end{array}$ \\
\hline & & b) the updated Articles of Association? \\
\hline & & $\begin{array}{l}\text { c) the internal regulation governing the functioning /its essential } \\
\text { aspects for each special commission/ specialized committee? }\end{array}$ \\
\hline & & d) the "Comply or Explain" Statement? \\
\hline & & $\begin{array}{l}\text { e) the list of the Supervisory Board members specifying which } \\
\text { members are independent, of the Executive Board and of the special } \\
\text { commissions/committees? }\end{array}$ \\
\hline & & $\begin{array}{l}\text { f) a brief version of the CV of each Supervisory Board and } \\
\text { Executive Board member? }\end{array}$ \\
\hline \multicolumn{2}{|c|}{$\mathrm{P} 2$} & $\begin{array}{l}\text { Does the Issuer respect the rights of the holders of the financial } \\
\text { instruments issued by the Issuer, ensuring equal treatment for them } \\
\text { while also submitting any change of the granted rights for approval } \\
\text { by the special meetings of such holders? }\end{array}$ \\
\hline \multirow{6}{*}{ P3 } & $\mathrm{R} 4$ & $\begin{array}{l}\text { Does the Issuer publish in a special section of its website the details } \\
\text { of the holding of the General Meetings of Shareholders ("GMS"): } \\
\text { a) the GMS convening notice? }\end{array}$ \\
\hline & & $\begin{array}{l}\text { b) the materials/documents relating to the items on the agenda, as } \\
\text { well as any other information about the items on the agenda? }\end{array}$ \\
\hline & & c) the templates of the special power of attorney? \\
\hline & R6 & $\begin{array}{l}\text { Has the Issuer drawn up and submitted for the GMS approval } \\
\text { procedures for an efficient and methodical holding of the GMS } \\
\text { according to procedure, however without prejudice to the right of } \\
\text { any shareholder to freely express their opinion on the topics subject } \\
\text { to the debates? }\end{array}$ \\
\hline & \multirow{2}{*}{$\mathrm{R} 8$} & $\begin{array}{l}\text { Does the Issuer disclose in a special section of its website the } \\
\text { shareholders' rights as well as the rules and procedures for the } \\
\text { attendance at GMS? }\end{array}$ \\
\hline & & $\begin{array}{l}\text { Does the Issuer provide the information in due time (immediately } \\
\text { after the GMS) to all shareholders through the special section on the } \\
\text { Issuer's website: }\end{array}$ \\
\hline
\end{tabular}




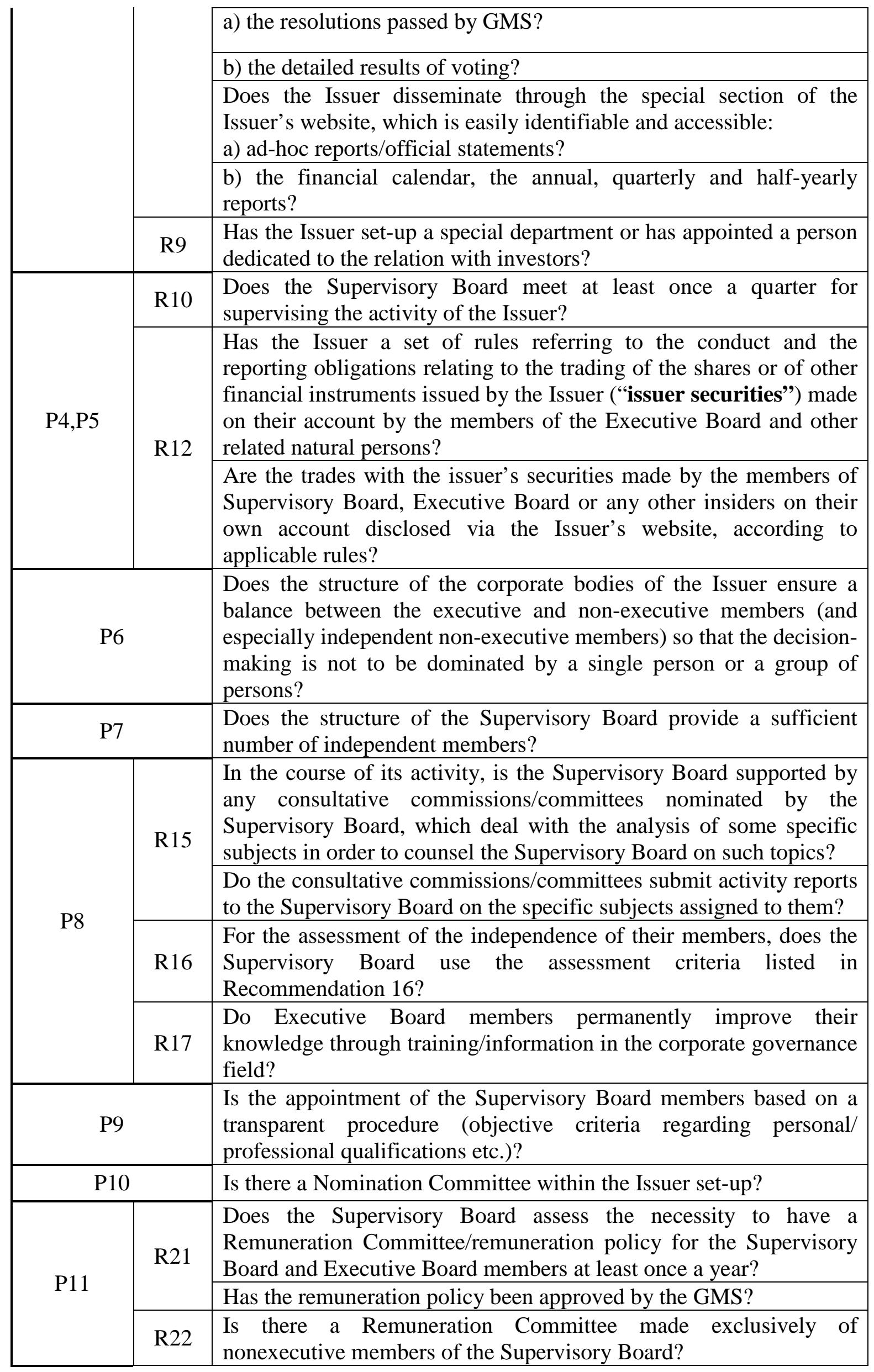




\begin{tabular}{|c|c|c|}
\hline & $\mathrm{R} 24$ & $\begin{array}{l}\text { Is the remuneration policy of the Issuer mentioned in the } \\
\text { Statute/Corporate Governance Regulation? }\end{array}$ \\
\hline \multirow{9}{*}{$\mathrm{P} 12, \mathrm{P} 13$} & \multirow{3}{*}{$\mathrm{R} 25$} & $\begin{array}{l}\text { Does the Issuer disclose the information subject of the reporting } \\
\text { requirements in English: } \\
\text { a) periodical information (regular providing information)? }\end{array}$ \\
\hline & & b) permanent information (continuous providing information)? \\
\hline & & $\begin{array}{l}\text { Does the Issuer prepare and make public the financial report } \\
\text { according to the IFRS standards? }\end{array}$ \\
\hline & $\mathrm{R} 26$ & $\begin{array}{l}\text { Does the Issuer organize, at least once a year, meetings with the } \\
\text { financial analysts, brokers, rating agencies and other market } \\
\text { specialists with the view to presenting the financial elements } \\
\text { relevant for the investment decision? }\end{array}$ \\
\hline & $\mathrm{R} 27$ & Is there an Audit Committee within the Issuer? \\
\hline & $\mathrm{R} 28$ & $\begin{array}{l}\text { Does the Supervisory Board or the Audit Committee, as the case } \\
\text { may be, assess on a regular basis the efficiency of financial } \\
\text { reporting, internal control and the risk management system } \\
\text { implemented by the Issuer? }\end{array}$ \\
\hline & R29 & $\begin{array}{l}\text { Is the Audit Committee comprised exclusively of nonexecutive } \\
\text { members of the Supervisory Board and is it comprised of a } \\
\text { sufficient number of independent members of the Supervisory } \\
\text { Board? }\end{array}$ \\
\hline & $\mathrm{R} 30$ & $\begin{array}{l}\text { Does the Audit Committee meet at least twice a year, with the view } \\
\text { to draw up and disclose to the shareholders half-yearly and annual } \\
\text { financial statements? }\end{array}$ \\
\hline & R32 & $\begin{array}{l}\text { Does the Audit Committee make proposals to the Supervisory Board } \\
\text { regarding the selection, the appointment, the re-appointment and the } \\
\text { replacement of the financial auditor, as well as the terms and } \\
\text { conditions of its remuneration? }\end{array}$ \\
\hline $\mathrm{P}$ & & $\begin{array}{l}\text { Has the Issuer approved a procedure with a view to identifying and } \\
\text { to settling any conflicts of interest? }\end{array}$ \\
\hline $\mathrm{P} 15$ & R33 & $\begin{array}{l}\text { Do the members of the Supervisory Board inform the Supervisory } \\
\text { Board on the conflicts of interests as they occur and do they refrain } \\
\text { from debates and the vote on such matters, according to relevant } \\
\text { legal provisions? }\end{array}$ \\
\hline P16 & $\begin{array}{l}\text { R34/ } \\
\text { R35 }\end{array}$ & $\begin{array}{l}\text { Has the Issuer approved the specific procedures in order to provide } \\
\text { the procedural compliance (criteria to identify the significant impact } \\
\text { of transactions, transparency, impartiality, non-competition etc.) } \\
\text { with the view to identify the transactions between related parties? }\end{array}$ \\
\hline $\mathrm{P} 17$ & R36 & $\begin{array}{l}\text { Has the Issuer approved a procedure regarding the internal flow and } \\
\text { disclosure to third parties of the documents and information } \\
\text { referring to the Issuer, considering especially inside information? }\end{array}$ \\
\hline P18 & $\begin{array}{l}\mathrm{R} 37 / \\
\mathrm{R} 38\end{array}$ & $\begin{array}{l}\text { Does the Issuer carry on activities regarding the Issuer's social and } \\
\text { environmental responsibility? }\end{array}$ \\
\hline
\end{tabular}


APPENDIX 2 - Companies' Websites

\begin{tabular}{|l|c|}
\hline \multicolumn{1}{|c|}{ Company } & Website \\
\hline BANCA COMERCIALA CARPATICA S.A & www.carpatica.ro \\
\hline BANCA TRANSILVANIA S.A & www.bancatransilvania.ro \\
\hline BRD - GROUPE SOCIETE GENERALE S.A. & www.brd.ro \\
\hline FONDUL PROPRIETATEA & www.fondulproprietatea.ro \\
\hline S.S.I.F. BROKER S.A. & www.ssifbroker.ro \\
\hline SIF BANAT CRISANA S.A. & www.sif1.ro \\
\hline SIF MOLDOVA S.A. & www.sifm.ro \\
\hline SIF MUNTENIA S.A. & www.sifmuntenia.ro \\
\hline SIF OLTENIA S.A. & www.sifolt.ro \\
\hline SIF TRANSILVANIA S.A. & www.siftransilvania.ro \\
\hline ANTIBIOTICE S.A. & www.antibiotice.ro \\
\hline BIOFARM S.A. & www.biofarm.ro \\
\hline BURSA DE VALORI BUCURESTI SA & www.bvb.ro \\
\hline C.N.T.E.E. TRANSELECTRICA & www.transelectrica.ro \\
\hline CONPET SA Ploiesti & www.conpet.ro \\
\hline ELECTRICA SA & www.electrica.ro \\
\hline ELECTROMAGNETICA SA BUCURESTI & www.electromagnetica.ro \\
\hline IMPACT DEVELOPER \& CONTRACTOR S.A & www.impactsa.ro \\
\hline OMV PETROM S.A. & www.petrom.com \\
\hline S.N. NUCLEARELECTRICA S.A. & www.nuclearelectrica.ro \\
\hline S.N.G.N. ROMGAZ S.A. & www.romgaz.ro \\
\hline S.N.T.G.N. TRANSGAZ S.A. & www.transgaz.ro \\
\hline
\end{tabular}

